\title{
Analysis of infant dietary data to investigate the nutritional adequacy of a milk exclusion diet
}

\author{
E. M. Oliver ${ }^{1}$, K. E. C. Grimshaw ${ }^{1}$, K. Scally ${ }^{1}$, K. Foote ${ }^{2}$ and G. Roberts ${ }^{1}$ \\ ${ }^{1}$ Clinical \& Experimental Sciences Academic Unit, Faculty of Medicine, University of Southampton, Southampton, UK \\ and ${ }^{2}$ Department of Paediatrics and Child Health, Royal Hampshire County Hospital, Southampton, UK
}

The exclusion of any nutrient from the diet may cause that diet to be nutritionally inadequate ${ }^{(1)}$. Prospective data was collected for infants enrolled into the UK birth cohort of Europrevall (a multicentre research project funded by the EU looking into allergy) ${ }^{(2)}$. A nested case-control study within the birth cohort was conducted to investigate the nutritional impact of a milk-free diet by comparing nutritional intake of those infants following a milk exclusion diet with those eating a normal diet for their age.

In the course of the parent study, infants suspected of reacting to cow's milk were placed onto a cow's milk free diet to see if symptoms improved. Mothers were given advice on how to exclude milk and all milk products from their infant's diet by the study dietitian. Food diaries were completed and returned every 4 weeks. The fourth week of each diary contained quantitative data to allow detailed dietary analysis of intake and it was this data that was used in this work. Diaries were analysed using the dietary analysis package 'CompEat' (Nutrition Systems) which had been modified to include the nutritional data for all formula milks, baby food products and milk-free products recorded. 13 symptomatic infants had at least three weeks milk-free quantitative data (covering 12 weeks in time) available for analysis. Each of these symptomatic infants had 2 control infants who were matched for age, number of weeks food diaries were returned and breastfeeding status (26 controls). Mean macro and micronutrients were compared using repeated measures ANOVA to see assess differences in nutrient intake between the groups.

The analysis showed mean daily Selenium $(P<0.03)$ and Vitamin $C(P<0.01)$ intake to be significantly different between infants consuming a milk free diet compared to infants consuming a normal diet. There was also a difference in nutrient intake between the groups at differing time points for the intake of protein, calcium, iron, selenium and vitamin $\mathrm{E}$.

\begin{tabular}{|c|c|c|c|c|c|}
\hline Nutrient & Time Point (weeks) & Age (weeks) & Subjects Symptomatic $(n=13)$ & Control $(n=26)$ & Significance \\
\hline Protein $(\mathrm{g})$ & $28-32$ & $\begin{array}{l}28 \\
32\end{array}$ & $\begin{array}{l}23.2(18.8-27.6) \\
25.1(22.9-27.3)\end{array}$ & $\begin{array}{l}17.5(13.4-21.6) \\
23.4(19.1-27.6)\end{array}$ & $P=0.039$ \\
\hline Calcium (mg) & $36-40$ & $\begin{array}{l}36 \\
40\end{array}$ & $\begin{array}{l}801.8(650.7-952.9) \\
710.0(572.6-847.4)\end{array}$ & $\begin{array}{l}677.1(594.2-760.0) \\
723.3(639.9-806.7)\end{array}$ & $P=0.025$ \\
\hline Iron $(\mathrm{mg})$ & $24-28$ & $\begin{array}{l}24 \\
28\end{array}$ & $\begin{array}{l}11.0(9.4-12.6) \\
11.1(9.4-12.8)\end{array}$ & $\begin{array}{l}7.1(6.3-7.9) \\
9.4(8.2-10.6)\end{array}$ & $P=0.028$ \\
\hline Selenium $(\mu \mathrm{g})$ & $24-28$ & $\begin{array}{l}24 \\
28\end{array}$ & $\begin{array}{l}12.8(10.9-14.7) \\
16.2(13.3-19.3)\end{array}$ & $\begin{array}{l}12.2(10.1-14.3) \\
12.3(11.2-13.4)\end{array}$ & $P=0.049$ \\
\hline Vitamin $\mathrm{E}(\mu \mathrm{g})$ & $32-36$ & $\begin{array}{l}32 \\
36\end{array}$ & $\begin{array}{l}7.5(5.4-9.6) \\
9.5(5.4-13.6)\end{array}$ & $\begin{array}{l}7.4(5.9-8.9) \\
6.9(6.0-7.7)\end{array}$ & $P=0.044$ \\
\hline
\end{tabular}

Values are given as means and $95 \%$ confidence intervals.

The results show that infants following a milk-free diet have a nutritional intake that was significantly different to their matched controls but that exclusion did not lead to a nutritionally deficient diet as intakes are well above RNI's. However, these observations cannot necessarily be applied to the general population as specialised nutrition intake advice is not widely available.

This work was funded by The Food Standards Agency, UK.

1. Grimshaw KEC (2006) Proc Nutr Soc 65(4), 412-7.

2. Keil T, McBride D, Grimshaw KEC et al. (2010) Allergy 65, 482-490. 